\title{
Gender differences in internet usage intentions for learning in higher education: An empirical study
}

\author{
Jimmy Macharia \& Emmanuel Nyakwende
}

\begin{abstract}
The processes of globalization present opportunities and challenges for higher education learners. This process increasingly depends upon information and communication technologies (ICTs) such as the internet. Despite the fact that there have been frequently observed male/female differences in ICT usage, this has not received adequate explanations especially in higher education internet usage. Consequently this paper presents the findings of an empirical study that adds insight and understanding into the causes of this difference. The study proposes a Technology acceptance model (TAM) to investigate the effect of gender differences in internet usage intentions in higher education. Four exogenous constructs namely, perceived relevance, perceived enjoyment, computer self-efficacy, computer anxiety, voluntariness, and two belief factors namely perceived ease of using the Internet, and perceived usefulness were modeled to influence behavioral intention in the TAM.
\end{abstract}

A questionnaire survey $(\mathrm{N}=1092)$ was administered and data were collected from university students in a selected sample of public and private universities in Kenya. Structural equation modeling (SEM) was used to examine the model. There exist significant gender differences in the influence of perceived ease of use and computer anxiety, influence on internet usage intentions for males and females. The influences of perceived ease of use, relevance to studies, and perceived enjoyment had significant influence on intentions for both males and females had a higher anxiety than males in using the internet. However, they had greater usage of the internet for their studies. Having a greater understanding of how males and females view internet usage for learning in their universities will contribute to deploying gender specific interventions in the usage of internet as a learning tool in and outside the classroom.

Keywords: Gender, SEM, Higher education, Technology Acceptance Model, Individual, Differences.

\section{Introduction}

Information and Communication Technologies (ICTs), are increasingly being accepted and integrated in teaching, learning and research agenda in universities in all the nations of the earth (Hites, 2005). The preference to incorporate ICTs is motivated by the prospective and actual benefits that grow from the use of ICT, such as increased access to education and better educational quality (Hashim, 2008). The use of ICTs can offer a rich selection of learning experiences that are suitable to the needs, pace, space, aspirations and learning methods (Phil, 2005). Learning and teaching could become interactive in contrast to the teacher-centered, and one-way delivery system in traditional face-to-face teaching. Further, the use of ICT could also promote self-learning (Phil, 2005). 
Despite the numerous benefits resulting from the use of ICTs in teaching and learning, there could also be negative consequences such as (i) students becoming distracted by pursuits such as illegal downloading of music and movies, (ii) use of online pornography, (iii) environmental hazards that emanate from disposing of obsolete computers, and (iv) the problem of gendered digital divide (GDD) manifested in observed gender disparities in both access and usage. Thus, this paper focuses on the latter dimension of ICTs. Recent studies have posited that there remains a gender imbalance despite a significant growth in ICT sector in recent years (Chiu, Lin, \& Tang, 2005; Hashim, 2008). This gender imbalance has been partly blamed for both the shortage of qualified ICT professionals, and the underrepresentation of some segments of the population, mostly females (Trauth \& Howcroft, 2006). Previous studies have stated that there is an urgent need to get women involved in the use of ICTs both as literate users and as professionals. This challenge applies to institutions and nations as well as to students and individuals (Gefen \& Straub, 1997; Wang, Liu, \& Jong, 2000). The problem of GDD is a disadvantage economically, socially, politically and educationally to those who do not access it or use it. The paper is an effort to further understand and propose possible interventions to overcome or reduce the GDD problem.

\section{Research framework}

This study uses a modified Technology Acceptance Model (TAM) (Davis, Bagozzi, \& Warshaw, 1989) which has over the years received better empirical support in information and communications technology studies than the theory of planned behavior (Ajzen, 1985). A further modification of TAM is necessary since TAM was created for a general explanation of the determinants of computer acceptance, rather than for the specific topic of behavioral intentions of internet (Venkatesh \& Bala, Technology Acceptance Model 3 and a Research Agenda on Interventions, 2008). The model of this study shown in figure 1 not only includes variables similar to the ones used in the TAM (Davis et al., 1989), such as perceived usefulness (Davis F. D., 1989) and perceived ease of purchasing (Davis F. D., 1989), but also integrates other critical variables specific to the learning environment and that are, relevant to gender and ICT studies (Sreberny, 2004; Wickramasinghe \& De Zoyza, 2006). Further, this study, apart from building on previous research by integrating several critical antecedent variables specific to internet usage, it also fills a gap in existing academic knowledge by empirically testing the main effects and moderating effects across gender during the formation of internet usage intentions. While various studies have indicated that some antecedent variables, for example, perceived usefulness, may influence internet usage intentions through attitudes indirectly (Taylor \& Todd, 1995b), others have argued for direct effects as well (Agarwal \& Karahanna, 2000). This study obtains empirical results, by testing direct and indirect influences. Consequently, the conceptual model herein hypothesizes that two antecedent constructs - namely, perceived ease of internet, and perceived usefulness have direct influences on internet usage intentions, while Computer Self Efficacy, Computer Anxiety, Perceived Enjoyment, Voluntariness, Relevance to Studies have indirect influences on internet usage intentions through the mediation of PU, and PEOU internet. 


\section{Group : Combined males \& females}



Figure 1: The research Framework

When genders stick to alternative sex roles, individuals with stronger feminine or masculine identities make different internet usage decisions accordingly. Some studies have argued that males are guided predominantly by controlling tendencies and stress self-assertion, selfefficacy, mastery, and avoidance of insecurity and uncertainty (Chiu, Lin, \& Tang, 2005). According Bandura (1986), self-efficacy is linked to perceived ability and may be defined as the belief that one has about capability to perform a particular behavior. The trend that gender can control once behaviour implies that the influence of self-efficacy and internet usage intentions may be moderated by gender, and such an influence is hypothesized to be stronger for male students than for females (Chiu, et al. 2005). Compared to the traditional learning tools such as reading printed books, the use of the internet for studies is an novel way to acquire additional learning resources for, learners. For this reason, the personal innovativeness of an individual student becomes critical to internet usage intentions. Based on the above review, the hypotheses for this paper are summarized as follows:

H1. The relationship between relevance and perceived usefulness is stronger for females than for males.

H2. The relationship between voluntariness and perceived ease of useis stronger for females than for males.

H3. The relationship between self-efficacy and perceived ease of use is stronger for males than for females.

H4. The relationship between perceived enjoyment and perceived ease of useis stronger for males than for females.

H5. The relationship between anxiety and perceived ease of useis stronger for males than for females.

Venkatesh and Morris, (2000) posits that the influence of perceived ease of use on intentions to utilize IT is stronger for females than for males, suggesting a greater impact of perceived ease of the internet for females than for males.. Females potentially have higher levels of computer anxiety (Igbaria, Zinatelli, Cragg, \& Cavaye, 1997) and consequently rate the 
hardiness of service and physical environment more highly than males. According to (Venkatesh \& Davis, 1996), this implies that the influence of perceived ease of use on IT usage may be moderated by gender, in which it may be stronger for females than for males.

Compared to females in general, a strong pattern is found among men who rate practical advancement highly (Chiu, Lin, \& Tang, 2005) by efficiently completing study tasks on the internet, indicating that usefulness rejecting a practical sense is more influential during the formation of internet usage intentions specifically for male students. This trend suggests that the influence of perceived usefulness on internet usage intentions may be moderated by gender, and the influence is stronger for males than for females. Based on the above review, the hypotheses are summarized as follows:

H6. The relationship between perceived usefulness and intention to use is stronger for males than for females.

H7. The relationship between self -perceived ease of use and intention to use is stronger for females than for males.

H8. The relationship between perceived ease of use and perceived usefulness is stronger for females than for males.

H9. The relationship between intention to use and usage is stronger for males than for females.

\section{Research methods}

This study was a cross sectional study which entailed the collection of data using a questionnaire survey of a sample of selected universities. in connection with several variables, which were then examined to discover patterns of association (Sekaran, 2003; Robey, 1996). Data collection methods were triangulated through the use of focus group discussions, interviews, observations and document reviews to examine the interaction of students with the internet in their studies.

\subsection{Subjects}

In this research, data was obtained from a large cross-sectional sample of students from a sample of private and public universities in Kenya. Sampling was conducted in three stages: , first, convenience sampling of private and public universities, followed secondly by proportionate stratified sampling for each selected university, thirdly random sampling of students in each university or strata. Convenience sampling is appropriate as the universities are neither serial nor acyclic. One thousand five hundred and fifty questionnaires were distributed to the respective universities, and the graduate assistants, in collaboration with faculty or students assistants in those universities, gave them to the students and made a follow-up for collection. One thousand and ninety two usable questionnaires were returned to the researchers (response rate of 72 percent), including males 52 percent and female 48 percent. The educational backgrounds for males comprising 93.5 percent undergraduates and 6.5 percent masters and for females comprising 85 percent undergraduates and 15 percent masters, reflect the fact that the average educational level is quite high for the sample. Table I also lists the distributions for age across gender. 
Table I: Distributions for age across gender.

\begin{tabular}{|l|l|l|l|l|l|l|}
\hline & \multicolumn{3}{|l|}{ Male } & \multicolumn{2}{l|}{ Female } & Total \\
\hline Age & No & $\%$ & No & $\%$ & No & $\%$ \\
\hline Below 20 Yrs & 49 & $8.6 \%$ & 136 & $26.0 \%$ & 185 & $16.9 \%$ \\
$21-30$ Yrs & 443 & $78 \%$ & 307 & 58.6 & 750 & $68.7 \%$ \\
$31-40$ Rrs & 58 & $10.2 \%$ & 54 & $10.3 \%$ & 112 & $10.3 \%$ \\
Oover 40 yrs & 18 & $3.2 \%$ & 27 & $5.1 \%$ & 45 & $4.1 \%$ \\
Total & 568 & $100.0 \%$ & 524 & $100.0 \%$ & 1092 & $100.0 \%$ \\
\hline
\end{tabular}

\subsection{Measures}

This study used constructs measured using seven-point Likert scales obtained and customized from the literature review. The constructs and their respective items were adopted and modified from various studies that are shown in Table II. The constructs were all designed by considering internet for university students context. This is important, because constructs related to internet usage intentions cannot be precisely measured if the target usage of internet is not made clear in the instrument. 
Table II: list of items used for developing each construct

\begin{tabular}{|c|c|c|}
\hline Construct & Items & Adapted from \\
\hline $\begin{array}{l}\text { Perceived } \\
\text { Usefulness }\end{array}$ & $\begin{array}{l}\text { 1. Using internet/www improves performance in my } \\
\text { learning \& study. 2. Using internet/www increases } \\
\text { my effectiveness in learning \& study. 3. Using } \\
\text { internet/www makes it easier to do my learning \& } \\
\text { study. 4. I find internet/www to be useful in my } \\
\text { learning\& study. }\end{array}$ & (Venkatesh \& Bala, 2008) \\
\hline $\begin{array}{l}\text { Perceived Ease } \\
\text { of Use }\end{array}$ & $\begin{array}{l}\text { 1.Learning to use the internet/www is easy for me, } \\
\text { 2. Interacting with internet/www does not require a } \\
\text { lot of my mental effort. 3.I find internet/www to be } \\
\text { easy to use, } 4 . I \text { find it easy to get internet/www to do } \\
\text { the work I want it to do. }\end{array}$ & $\begin{array}{l}\text { (Davis, 1989; Venkatesh \& Bala, } \\
\text { 2008) }\end{array}$ \\
\hline $\begin{array}{l}\text { Intention to } \\
\text { Use }\end{array}$ & $\begin{array}{l}\text { 1. I intend to use the internet/www for my learning \& } \\
\text { studies, } 2 \text {. I intend to use the internet/www, for social } \\
\text { activities and general information }\end{array}$ & $\begin{array}{l}\text { (Davis, 1989; Venkatesh \& Bala, } \\
\text { 2008; }\end{array}$ \\
\hline Usage & $\begin{array}{l}\text { On average, how much time do you spend each day } \\
\text { on the Internet__ Hrs }\end{array}$ & $\begin{array}{l}\text { (Davis et al., 1989), (Venkatesh \& } \\
\text { Davis, 2000) }\end{array}$ \\
\hline $\begin{array}{l}\text { Computer } \\
\text { Self- Efficacy }\end{array}$ & $\begin{array}{l}\text { I could complete the job using a software package } \ldots \\
, 1 \ldots . . \text { if there was no one around to tell me what to do } \\
\text { as I go. } 2 \ldots \text {..if I had just the built-in help facility for } \\
\text { assistance. } 3 \ldots \text { if someone showed me how to do it } \\
\text { first. } 4 \ldots . . \text { if I had used similar packages before this } \\
\text { one to do the same job. }\end{array}$ & $\begin{array}{l}\text { (Luarn \& Lin, 2005; Wang, Liu, \& } \\
\text { Jong, 2000) }\end{array}$ \\
\hline $\begin{array}{l}\text { Computer } \\
\text { Anxiety }\end{array}$ & $\begin{array}{l}\text { 1. Computers do not scare me at all, 2. Working with } \\
\text { a computer makes me nervous, } 3 \text {. Computers make } \\
\text { me feel uncomfortable, } 4 \text {. Computers make me feel } \\
\text { uneasy. }\end{array}$ & Venkatesh \& Bala, 2008 \\
\hline $\begin{array}{l}\text { Perceived } \\
\text { Enjoyment }\end{array}$ & $\begin{array}{l}\text { 1. I find using the ICTs to be enjoyable, } 2 \text {. The actual } \\
\text { process of using the ICTs is pleasant. I have fun using } \\
\text { the ICTs. }\end{array}$ & Venkatesh \& Bala, 2008; \\
\hline Voluntariness & $\begin{array}{l}\text { 1. My use of the internet is voluntary, 2. My } \\
\text { university/lecturers does not require me to use the } \\
\text { internet, 3. Although it might be helpful, using the } \\
\text { internet is certainly not compulsory in my job. }\end{array}$ & (Venkatesh \& Davis, 2000) \\
\hline $\begin{array}{l}\text { Relevance to } \\
\text { Studies }\end{array}$ & $\begin{array}{l}\text { 1. In my studies, usage of the internet/www is } \\
\text { important, 2. In my studies, usage of the } \\
\text { internet/www is relevant. } 3 \text {. The use of the internet is } \\
\text { pertinent/www to my various studies-related tasks. }\end{array}$ & Venkatesh \& Bala, 2008 \\
\hline Gender & 1. What is your gender & \\
\hline Age & What is your age & \\
\hline $\begin{array}{l}\text { Internet } \\
\text { Experience }\end{array}$ & For how long have you used the Internet & \\
\hline
\end{tabular}

\subsection{Measurement model}

The reliability in this research was evaluated using Cronbach's alpha. As shown in Table III, The reliabilities (Cronbach's alpha) for all constructs exceed 0.7 except one. Consequently the reliability of this study meets threshold level of acceptable reliability according to (Nunnally, 1978). Hence, the common requirement of reliability for study instruments is 
satisfactory. Moreover, in this study, for all three models (total group, male group, and female group) all factor loadings for indicators measuring the same construct are statistically significant indicating that all indicators effectively measure their corresponding construct (Straub, Boudreau, \& Gefen, 2004; Madu, 1998) and support convergent validity.

Table III, reliabilities (Cronbach's alpha)

\begin{tabular}{|l|l|l|}
\hline Construct & Items & Cronbachs'alpha \\
\hline Perceived Usefulness & 4 & 0.907 \\
\hline Perceived Ease of Use & 4 & 0.826 \\
\hline Intention to Use & 2 & 0.834 \\
\hline Usage & 2 & 0.833 \\
\hline Computer Self Efficacy & 4 & 0.742 \\
\hline Computer Anxiety & 3 & 0.874 \\
\hline Perceived Enjoyment & 3 & 0.856 \\
\hline Voluntariness & 3 & 0.535 \\
\hline Relevance to Studies & 3 & 0.861 \\
\hline
\end{tabular}

\subsection{Structural model}

Following the first step, the second step analyzing the structural models was then performed. Figure 2 shows the path coefficients of the structural model.

$$
\begin{gathered}
\text { Chi-square }=1563.125(81 \mathrm{df}) \\
\mathrm{p}=.000
\end{gathered}
$$

\section{Group : Combined males \& females}

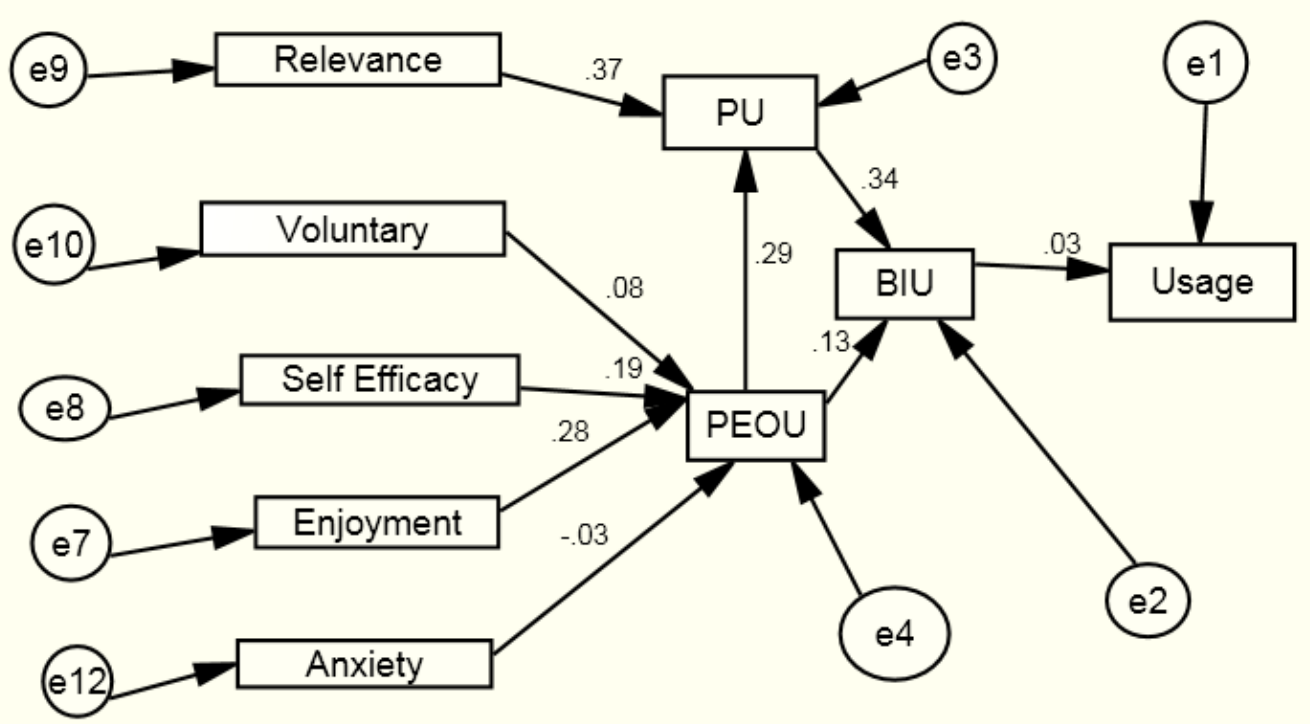

Figure 2: Path coefficients 


\section{Results}

Table III lists the empirical test results based on the male and female group samples. Two path $\mathrm{H} 3$ and $\mathrm{H} 9$ for male group and three paths (H2,H5, and H9) for female group were not supported while the remaining paths are all significant $(\mathrm{H} 1, \mathrm{H} 3, \mathrm{H} 4, \mathrm{H} 6, \mathrm{H} 7$, and $\mathrm{H} 8)$ were supported.

Table III lists the test results

\begin{tabular}{|c|c|c|c|c|c|c|c|c|c|}
\hline \multirow{2}{*}{\multicolumn{3}{|c|}{ Hypothesis }} & \multicolumn{3}{|c|}{$\begin{array}{l}\text { Standardized Path } \\
\text { coefficient Male Group }\end{array}$} & \multicolumn{3}{|c|}{$\begin{array}{l}\text { Standardized Path } \\
\text { coefficient Female Group }\end{array}$} & \multirow{3}{*}{$\begin{array}{l}\text { Male } \\
\text { versus } \\
\text { Femal } \\
\text { e } \\
\text { M>F }\end{array}$} \\
\hline & & & \multirow{2}{*}{$\begin{array}{l}\text { Estimate } \\
0.315 \\
\end{array}$} & \multirow{2}{*}{\begin{tabular}{|l|} 
S.E. \\
0.033 \\
\end{tabular}} & \multirow{2}{*}{\begin{tabular}{|l}
$\mathrm{P}$ \\
$* * *$
\end{tabular}} & \multirow{2}{*}{$\begin{array}{l}\begin{array}{l}\text { Estimat } \\
\text { e }\end{array} \\
0.186 \\
\end{array}$} & \multirow{2}{*}{$\begin{array}{l}\text { S.E. } \\
0.041 \\
\end{array}$} & \multirow{2}{*}{$\begin{array}{l}\mathrm{P} \\
* * *\end{array}$} & \\
\hline $\mathrm{H} 4$ & PENJ --> & PEOU & & & & & & & \\
\hline $\mathrm{H} 3$ & CSE --> & PEOU & 0.167 & 0.035 & $* * *$ & 0.211 & 0.046 & $* * *$ & $\mathrm{M}>\mathrm{F}$ \\
\hline H5 & CA --> & PEOU & -0.026 & 0.033 & 0.428 & -0.026 & 0.039 & 0.506 & $\mathrm{M}=\mathrm{F}$ \\
\hline $\mathrm{H} 2$ & VOL --> & PEOU & 0.098 & 0.031 & 0.002 & 0.041 & 0.04 & 0.317 & $\mathrm{M}>\mathrm{F}$ \\
\hline $\mathrm{H7}$ & PEOU --> & $\mathrm{PU}$ & 0.223 & 0.04 & $* * *$ & 0.371 & 0.039 & $* * *$ & $\mathrm{~F}>\mathrm{M}$ \\
\hline H1 & REL --> & PU & 0.402 & 0.036 & $* * *$ & 0.321 & 0.039 & $* * *$ & $\mathrm{M}>\mathrm{F}$ \\
\hline H6 & PU --> & BIU & 0.379 & 0.044 & $* * *$ & 0.348 & 0.046 & $* * *$ & $\mathrm{M}=\mathrm{F}$ \\
\hline $\mathrm{H} 8$ & PEOU --> & BIU & 0.157 & 0.047 & $* * *$ & 0.13 & 0.047 & 0.006 & $\mathrm{M}=\mathrm{F}$ \\
\hline H9 & BIU --> & Usage & 0.001 & 0.028 & 0.971 & 0.062 & 0.033 & 0.061 & $\mathrm{~F}>\mathrm{M}$ \\
\hline
\end{tabular}

Notes: *p , 0:10; **p , 0:05 and *** p , 0:01

Table IV: presents the T-test for equality of means for the two groups namely male and female of the variables Perceived Usefulness, Perceived Ease of Use, Computer self Efficacy, Computer anxiety, Perceived, Enjoyment, Voluntariness, relevance, Behavioural Intention and Usage.

Table IV: T-test for Equality of Means

\begin{tabular}{|l|r|r|r|r|r|}
\hline & $\mathrm{t}$ & $\mathrm{Df}$ & $\begin{array}{l}\text { Sig. } \\
(2- \\
\text { tailed })\end{array}$ & $\begin{array}{l}\text { Mean } \\
\text { Difference }\end{array}$ & $\begin{array}{l}\text { Male } \\
\text { Versus } \\
\text { Female }\end{array}$ \\
\hline $\begin{array}{l}\text { Perceived } \\
\text { Usefulness }\end{array}$ & 3.05 & 1090 & 0.002 & 0.27 & $\mathrm{M}>\mathrm{F}$ \\
\hline $\begin{array}{l}\text { Perceived } \\
\text { Ease of use }\end{array}$ & 1.64 & 1090 & 0.102 & 0.14 & $\mathrm{M}>\mathrm{F}$ \\
\hline Self-Efficacy & 0.46 & 1090 & 0.644 & 0.04 & $\mathrm{M}>\mathrm{F}$ \\
\hline $\begin{array}{l}\text { Computer } \\
\text { Anxiety }\end{array}$ & -2.98 & 1090 & 0.003 & -0.27 & $\mathrm{~F}>\mathrm{M}$ \\
\hline Enjoyment & 2.77 & 1090 & 0.006 & 0.25 & $\mathrm{M}>\mathrm{F}$ \\
\hline Voluntariness & -1.27 & 1090 & 0.203 & -0.12 & $\mathrm{M}>\mathrm{F}$ \\
\hline Relevance & 1.49 & 1090 & 0.137 & 0.13 & $\mathrm{M}>\mathrm{F}$ \\
\hline Intention & 3.52 & 1090 & 0.000 & 0.33 & $\mathrm{M}>\mathrm{F}$ \\
\hline Usage & -2.85 & 1090 & 0.004 & -0.19 & $\mathrm{~F}>\mathrm{M}$ \\
\hline
\end{tabular}


Based on the results of Levene's test, violation of the assumption of homoscedasticity is not supported, given an $\alpha$ of less than .05 ( $\mathrm{p}$-value < 0.5) for Perceived Usefulness, Perceived Ease of Use, Computer self Efficacy, Perceived, Enjoyment, Voluntariness, relevance, Behavioural Intention and Usage. So, the t test results based on "Equal variances assumed" is interpreted.

\section{Discussion and managerial implications}

The test results of this study reveal that one antecedent construct - namely, Relevance to Studies, has indirect influence via Perceived Usefulness, while four antecedent construct namely Computer Self Efficacy, Computer Anxiety, Perceived Enjoyment, Voluntariness have indirect influence via Perceived Ease of Use of the internet on internet usage intentions. These findings suggest that boosting the five antecedents can simultaneously increase students intentions to use the internet except for voluntariness and anxiety.

Regarding the main effects of gender, the significant difference for the means of two exogenous constructs (perceived ease of use of the internet and perceived usefulness) across the subgroups leads to following suggestions for higher education. To begin with, the significantly lower mean of perceived ease of internet for female students compared to males indicates that female students tend to give a lower evaluation than males of the effortlessness of internet. This unique finding is very helpful for higher education, indicating that a userfriendly system which facilitates internet usage should be emphasized during orientation and literacy training. Besides, word-of-mouth broadcasting by other female students may be another important approach to help female students overcome hurdles and barriers to accepting internet usage for their learning, especially during the early years of study. Establishing an internet-based social group forum based on gender and studies provides another method of improving female perceptions of ease of using the internet owing to the effective communications among female students themselves.

The significantly lower mean of computer anxiety for males compared to females indicates that male students are less likely to consider the internet problematic. The lower computer anxiety score for male students reveals that male students do not find the internet usage fearful. A comparison of genders reveal that males tend to expose more "masculine" traits (Chiu, Lin, \& Tang, 2005) such as being assertive, impatient, and goal-oriented (Venkatesh and Morris, 2000), indicating that they desire to successfully accomplish efficient internet usage without distraction. Nevertheless, due to the overwhelming explosion of information on the internet, it takes a longer time for students to search and select useful information for their studies, causing lower mean scores of computer anxiety for male students. This remarkable finding is important for higher education. The evidence suggests that female students are more anxious when using the internet for their studies. This could be attributed to the uncertainty attributed with the time it takes, and the difficult task of determine the relevance of the information obtained. This finding suggests a need for an efficient internet system that may require search mechanisms designed to help students compare content from different internet sources, thus producing an extensive list of comparative content to enable students to rapidly identify relevant information. Features such as improving usage speed are also important for female students. For example, offering an expert endorsement of the most popular study relevant content on the first page of a website to be accessed via a single click would facilitate female students to make the decisions efficiently to access the resource. This is because female students tend to be more anxious and hence prefer to visit the sites with 
readily available and useful information that can provide quick advice. Finally, offering female students the right internet content whenever they need it and placing it a click away can strengthen the usage intentions of female students.

The finding of significant gender differences provides additional support to psychological theories, stating that males and females have different gender-based perceptions (Venkatesh and Morris, 2000) which can influence their preferences and decisions during interaction with internet for their studies. The implications of this study can be applied to the wireless area where students can surf with their cell phones to learn and listen to videos, et cetera, from higher education institutions. Universities might consider the importance of corresponding regularly with students via the internet, thus providing students with substantive information from the perspective of gender differences. Learning gender differences is critical, as educators and institutions can better target students and consequently foster more internet usage intentions.

\section{Limitations and future research directions}

This research has some limitations relating to data collection and results' interpretation. The first limitation is the possibility of a common method bias by using a single questionnaire to measure all constructs. Another limitation was that this study has been conducted in the higher education sector of a single country setting (Kenya). As a result, the generalisability of the findings might be limited. Further, research across different countries will be required in order to generalize the findings. The third limitation in this study is using only one ICT artifact category (internet), which may seem gender-specific given that ICTs are considered appealing to male students. The fourth limitation arises from some indicators being removed during the measurement model testing. Lastly, this study in fact measured subjects' intentions and attitudes towards behavior rather than actual behavior. However, intentions may not be necessarily perfect predictors of behaviors. Therefore, a future study can try to improve such a shortcoming by directly observing the subjects over time. Future studies can take note of these shortcomings in planning future research work by, for example, specifying to some different models. It would be also interesting for future studies to investigate whether other countries and sectors also display similar gender differences in internet usage intentions.

\section{References}

Agarwal, R., \& Karahanna, E. (2000). Time Flies When You're Having Fun: Cognitive Absorption and Beliefs about Information Technology Usage. MIS Quarterly, 24 (4), 665-694.

Ajzen, I. (1985). From intentions to actions: a theory of planned behaviour. Action, 11-39, viewed 20 February 2008, $<\mathrm{http}$ //search.epnet.com/login.aspx ?direct=true \&db=aph\&authdb=epref\&an=ACFCB.AJZEN.SP RINGER.AIHE.AA >.

Bandura, A. (1986). Social foundations of thought and action: a social cognitive theory. Englewood Cliffs, N.J.: Prentice-Hall series in social learning theory, PrenticeHall.

Chiu, Y. B., Lin, C. P., \& Tang, L. L. (2005). Gender differs: assessing a model of online purchase intentions in e-tail service. Retrieved from http://www.emeraldinsight.com/Insight/viewContentItem.do?contentType=Article\&contentId=15 23880. International Journal of Service Industry Management , 16 (5), 416-435.

David, G., \& Detmar, S. (1997). Gender Differences in the Perception and Use of E-Mail: An Extension to the Technology. MIS Quarterly, 21 (4), 389-400.

Davis, F. D. (1989). Perceived Usefulness, Perceived Ease of Use, and User Acceptance of Information Technology. MIS Quarterly, 13 (3), 318-339. 
Davis, F. D., Bagozzi, R. P., \& Warshaw, P. R. (1989). User acceptance of computer technology: A comparison of two theoretical models. Management Science, 35, 982-1003.

Gefen, D., \& Straub, D. ,. (1997). Gender Differences in the Perception and Use of E-Mail: An Extension to the Technology Acceptance Model. MIS Quarterly, , 21 (4), 389-400.

Goldberg, A. K. (2005). Exploring Instructional Design Issues with Web-Enhanced Courses:What Do Faculty Need in Order to Present Materials On-Line and What Should They Consider When Doing So? Journal of Interactive Online Learning , 4 (1), 40-52.

Hashim, J. (2008). Learning barriers in adopting ICT among selected working women in Malaysia. Gender in Management: An International Journal , 23 (5), 317-336.

Hites, M. (2005). Information and Communication Technologies. New Mexico State University.Retrived May 14, 2008 from,http://uno-project.nmsu.edu,.

Igbaria, M., Zinatelli, N., Cragg, P., \& Cavaye, A. (1997). Personal computing acceptance factors in small firms: A structural equation model. MIS Quarterly, 21 (3), 279-305.

Luarn, P., \& Lin, H.-H. (2005). Toward an understanding of the behavioral intention to use mobile banking. Computers in Human Behavior 21 (2005), 21 (2), 873-891.

Madu, C. N. (1998). An empirical assessment of quality: research considerations. International Journal of Quality Science, 348-355.

Ndubisi, N. O. (2004). Factors influencing e-learning adoption intention: Examining the determinant structure of the decomposed theory of planned behaviour constructs. HERDSA 2004 conference proceedings (pp. 252-262). Universiti Malaysia Sabah.

Nunnally, J. C. (1978). Psychometric theory (2nd ed. ed.). New York: McGraw-Hill.

Phil, R. (2005). Making Learning Happen’ Chapter 5: Learning through feedback. London: sAGE.

Robey, D. (1996). Research Commentary: Diversity in Information Systems Research: Threat, Promise, and Responsibility. Information Systems Research, 7, 400-408.

Sekaran, U. (2003). Research Methods For Business: A Skill Building Approach. Singapore: John Wiley \& Sons.Retrived Dec 2007

from,http://scholar.google.com/scholar?q=Research+Methods++For+Business:+A+Skill+Buildin $\mathrm{g}+$ Approach \&hl=en $\& u m=1 \& \mathrm{ie}=\mathrm{UTF}-8 \&$ oi $=$ scholart.

Sreberny, A. (2004). Gender, empowerment, and communication: looking backwards and forwards. UNESCO, 285-300.

Straub, D., Boudreau, M.-C., \& Gefen, D. (2004). Validation guidelines for IS positivist research. Communications of the Association for Information Systems , 13, 380-427.

Taylor, S., \& Todd, P. (1995b). Understanding information technology usage: a test of competing models. Information Systems Research , 6, 144-76, viewed 30 August 2007,<http://search.epnet.com/login.aspx?direct=true\&db=aph\&authdb=epref\&an=ISR.F.ADD.T AYLOR.UITUTC > .

Trauth, E. M., \& Howcroft, D. (2006). Critical empirical research in IS: an example of gender and the IT workforce. Information Technology \& People , 19 (3), 272-292.

Venkatesh, V., \& Bala, H. (2008). Technology Acceptance Model 3 and a Research Agenda on Interventions. Decision Sciences , 39 (2), 273-315.

Venkatesh, V., \& Davis, F. (1996). A Model of the Antecedents of Perceived Ease ofUse: Development and Test. Decision Sciences , 27 (3), 451-481, viewed 20 July 2007,<http://search.epnet.com/login.aspx?direct=true\&db=aph\&an=10758835 >.

Venkatesh, V., \& Morris, M. G. (2000). Why don't men ever stop to ask for directions? Gender, social influence, and their role in technology acceptance and usage behavior. MIS Quarterly, 24 (1), 115-139.

Wang, T.-S., Liu, H.-J., \& Jong, D. (2000). TAM Reasons for Gender Treason in Technology Change. Proceedings of the Fifth IEEE International Conference on Advanced Learning Technologies, (pp. 1-2).

Wang, Y.-S., Wang, Y.-M., Lin, H.-H., \& Tang, T.-I. (2003). International Journal of Service Industry Management. Determinants of user acceptance of Internet banking: an empirical study, 14 (5), 501-519.

Wickramasinghe, V., \& De Zoyza, N. (2006). Gender, age and marital status as predictors of managerial competency needs. Gender in Management: An International Journal , 23 (5), 337-354. 